This is an author produced version of a paper published in Livestock Science. This paper has been peer-reviewed and is proof-corrected, but does not include the journal pagination.

Citation for the published paper:

Hultgren, J., Svensson, C., Pehrsson, M., 2011. Rearing conditions and lifetime milk revenues in Swedish dairy cows. Livestock Science 137, 108-115.

doi:10.1016/j.livsci.2010.10.005

http://www.sciencedirect.com/science/article/pii/S18711413100 05536

Access to the published version may require journal subscription.

Published with permission from: Elsevier

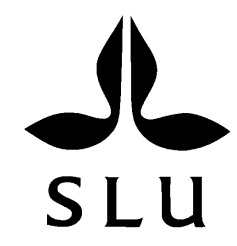

Epsilon Open Archive http://epsilon.slu.se 


\title{
Rearing conditions and lifetime milk revenues in Swedish dairy cows
}

\author{
Jan Hultgren, ${ }^{\mathrm{a}, *}$, Catarina Svensson ${ }^{\mathrm{a}, 1}$ and Mats Pehrsson ${ }^{\mathrm{b}, 2}$ \\ ${ }^{\text {a }}$ Department of Animal Environment and Health, Swedish University of Agricultural Sciences, \\ P.O. Box 234, SE-532 23 Skara, Sweden \\ ${ }^{\mathrm{b}}$ Swedish Dairy Association, P.O. Box 210, SE-101 24 Stockholm, Sweden
}

\begin{abstract}
Associations between replacement heifer rearing conditions and lifetime milk revenues were studied throughout the productive life of Swedish dairy cows. Data were collected from 2127 cows, mainly Swedish Reds and Swedish Holsteins, representing all female animals born during 1998 in 110 herds and followed until May 2006. Lifetime net milk revenues were calculated for each cow based on the length of productive life, lifetime milk production, a fixed milk price of $0.3 € / \mathrm{kg} \mathrm{ECM}$, and estimated costs for heifer rearing and cow feed. Median observed productive lifetime to culling, death, selling off or terminated recording was 26.9 mo. Mean lifetime production was $9209 \mathrm{~kg}$ ECM/cow-yr, calculated from monthly testday yields. Rearing costs (median $631 €$ ) were estimated using a template developed for Swedish advisory services, including costs related to purchase, feeding, labour, building investment, building maintenance and breeding. Net milk revenues had a median of 1169 $€ /$ cow-yr during productive life and were heavily skewed. Diarrhea and respiratory disease before $7 \mathrm{mo}$ of age had occurred in 11 and $11 \%$ of the cows, respectively, the majority cases being mild. The mean prepubertal growth rate was $670 \mathrm{~g} /$ day. Cow net revenue values were transformed to achieve normality and analysed by a linear mixed model including fixed effects of breed, calf housing system from 3 to 7 mo of age, body condition score at 1st breeding, year of 1 st calving, age at 1st calving, cow housing system, mean milk cell count, the interaction between calf housing and breed, the interaction between cow housing and breed, and the random effect of herd. The model predicted net revenues to decrease with age at 1 st calving and with body condition score at breeding over 4 . Our results show that replacement rearing factors influence net milk revenues of a dairy operation and suggest that current recommendations to breed dairy heifers for calving at 24 mo are economically justified.
\end{abstract}

Keywords: Dairy cattle; Health; Milk production; Rearing; Replacement heifer; Revenue

\footnotetext{
* Corresponding author. Tel.: +46 511 67103; fax.: +46 511 67204. E-mail address: jan.hultgren@ @mh.slu.se (J. Hultgren)

${ }^{1}$ Present address: Hansa Husdjur Regional Dairy Association, P.O. Box 814, SE-391 28 Kalmar, Sweden

${ }^{2}$ Present address: Faculty of Veterinary Medicine and Animal Science, Swedish University of Agricultural Sciences, Kungsängen 6B, SE-753 23 Uppsala, Sweden
} 


\section{Introduction}

The profitability of a dairy operation is largely determined by milk revenues and feed costs. Strandberg (1992) reported that almost $95 \%$ of the variation in income and cost during a cow lifetime was due to these two items. Profitability can be achieved by a high milk production or by low feed costs. Studies of factors affecting milk production have mainly focused on the adult cow, largely overlooking rearing factors that might have had an influence on later performance in the cow herd. Considering rising production levels, it seems reasonable that cows are increasingly susceptible to factors limiting the expression of the genetic potential for milk production.

A calving age of 24 mo or less has been recommended for maximized profit, despite a lower production during first lactation (Lin et al., 1988; Pirlo et al., 2000). However, few farms achieve recommended targets and considerably higher calving ages are generally reported. In Sweden, the average age at 1st calving is approximately 28 mo (Swedish Dairy Association, 2009).

There is substantial evidence of a negative effect of high weight gains during the period of allometric mammary growth (i.e., from approximately 90 to $300 \mathrm{~kg}$ of body weight; Sejrsen et al., 1982). At an early calving, accelerated postpubertal growth was found to be associated with lower first-lactation milk production (Hoffman et al., 1996). Contradicting results have, however, been reported (Gardner et al., 1988; Pirlo et al., 1997). From experimental studies, prepubertal growth rates up to $799 \mathrm{~g}$ /day have been associated with increasing milk production, whereas higher rates have been reported to have a detrimental effect on udder parenchyma and production (Sejrsen et al., 2000; Zanton and Heinrichs, 2005).

Few studies have focused on the influence of calfhood health on subsequent milk production and most have used small numbers of animals (Britney et al., 1985). Numerous experimental studies have reported on effects of feeding regimes and daily weight gains, but these have mostly dealt with first-lactation production and few explore associations with multi-lactational production. Epidemiological data might help to clarify discrepancies between studies. By combining observations on heifer rearing, cow housing, management, milk production and life length at commercial operations, relationships between rearing factors, calving age and lifetime milk production and revenues can be revealed and expressed in monetary terms.

Our objective was to study associations between factors related to heifer rearing and lifetime milk revenues in Swedish commercial dairy herds. Focus was on the influence of calfhood housing and disease, prepubertal growth, feeding around 1st calving and age at 1st calving.

\section{Material and methods}

\subsection{Data}

Data were collected from heifer calves born during 1998 in 122 southwest Swedish dairy herds. Totally 3081 heifer calves were enrolled, out of which 2243 were later reported to calve as heifers in the study herds. Recordings continued until May 2006. After editing and exclusion of incomplete data, 2127 complete cow lifetime records from 110 herds were possible to include. The animals were Swedish Red cows (49\%), Swedish Holsteins (49\%) or cows of other or mixed breeds. Their health until calving was described by Svensson et al. (2003, 2006a) and Hultgren et al. (2008), based on the same data. Herd selection, data 
collection and herd management were described by Svensson and Hultgren (2008) and by Hultgren and Svensson (2009).

Calf housing was represented by two different categories each for slatted and litter pens (small and large pens; large denoting pens with $>7$ and $>12$ calves, respectively), and a separate category for calves in other systems (tie-stalls or, in one large herd, cubicles). The categories were chosen based on current housing practices.

Body weight was estimated from heart girth at weaning and at 1st breeding, and daily growth rate between these to time points was calculated as previously described by Hessle et al. (2004) and denoted prepubertal growth rate. In lactations with missing values (11\% of cows), the growth rate was set to the overall mean within breed.

The costs of rearing a heifer until calving (depending on calving age) were estimated by a calculus template developed in advisory services offered by the Swedish Dairy Association, including fixed items listed in Table 1. Building costs per year during rearing were calculated

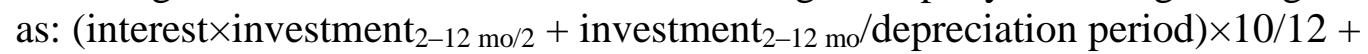
(interest $\times$ investment $>12 \mathrm{mo} / 2+$ investment $_{>12 \mathrm{mo}} /$ depreciation period $) \times($ calving age -1$)$, where only calving age (expressed in years)was allowed to vary. The calculus was previously validated through extensive practice. For each cow, yearly lifetime rearing costs were calculated by dividing estimated rearing costs by the length of productive life.

\section{Table 1}

Fixed items included in calculation of heifer rearing costs until 1st calving at 22 to 35 mo of age.

\begin{tabular}{lc}
\hline Item & Amount \\
\hline Purchase cost of baby calf $(€)$ & 137 \\
Mean feed consumption (kg dry matter/day) & 6.7 \\
Feed price $(€ /$ kg dry matter) & 0.125 \\
Labour time during rearing $(\mathrm{h})$ & 12 \\
Labour price $(€ / \mathrm{h})$ & 19 \\
Building investment cost age $2-12$ mo $(€)$ & 1500 \\
Building investment cost age $>12$ mo $(€)$ & 1000 \\
Depreciation period for building investments $(\mathrm{yr})$ & 18 \\
Yearly interest $(\%)$ & 5 \\
Maintenance of building $(€ / \mathrm{yr})$ & 15 \\
Breeding services $(€)$ & 40 \\
Miscellaneous costs age $2-12$ mo ${ }^{\text {a }}(€ /$ mo) & 3.50 \\
\hline a Including bedding material, milk recording and advisory services, veterinary \\
treatments and drugs, electric power, animal insurances, maintenance of housing \\
equipment, and fuel and maintenance of a tractor.
\end{tabular}

Daily milk yields for each cow and day from 1st calving to culling, spontaneous death or selling live, or to end of recording on 31 May 2006, were estimated from monthly test-day recordings obtained from the Swedish official milk recording scheme (Olsson et al., 2001). Between calving and the 1st test day of a lactation, daily yields were calculated using a polynomial of lactation day based on all test-day recordings from 4 to $305 \mathrm{~d}$ post calving in all project cows, estimated by least-squares regression within each breed (Swedish Red, Swedish Holstein, or other) and parity (1,2 or $\geq 3)$ separately. After exploring simpler models, a sixth degree polynomial was used. Between test days and on test days with missing recordings, daily milk yields were set to the latest recorded value. Yields were set to 0 during the dry period, assumed to start 50 days pre calving, if milk recordings did not indicate differently. Each cow's yearly lifetime milk production was calculated as the sum of all daily 
yields during her productive life, including dry periods, divided by the total number of days and multiplied by 365. Composite somatic milk cell counts were summarized on cow level as the geometric mean of all test-day values, and on herd level as the geometric mean of all individual cow values in 2001 .

For each cow, lifetime net milk revenues were calculated as the estimated yearly lifetime milk production multiplied by a fixed milk price of $0.3 € / \mathrm{kg} \mathrm{ECM}$, and subtracted by estimated yearly lifetime rearing costs per year, and by estimated cow feed costs corresponding to $1 / 3$ of the milk revenues. The Swedish University of Agricultural Sciences has estimated feed costs to equal on average $30-40 \%$ of gross milk revenues (http://www.agriwise.org/, not published). Net milk revenue values were heavily skewed to the left with a maximum around $2500 € / \mathrm{cow}-\mathrm{yr}$. To achieve a near-to-normal distribution, the variable was transformed by reversing the sign, adding $2500 € / \mathrm{cow}-\mathrm{yr}$ and then taking the natural logarithm, i.e. transformed net revenues $=\ln (2500-$ net revenues $)$.

\subsection{Statistical analysis}

Data were edited and descriptive statistics were created in JMP 8 Statistical Discovery software (SAS Institute Inc., Cary, NC, USA) and Microsoft Excel 2007 (Microsoft Corp., Redmond, WA, USA). Modelling of yearly lifetime milk production was performed using the MIXED procedure of SAS 9.1 statistical software package (SAS Institute Inc., Cary, NC, USA), applying the following linear mixed model:

$$
Y_{i j}=\beta_{0}+u_{0 j}+\sum \beta_{\mathrm{m}} X_{\mathrm{m} i j}+e_{i j}
$$

where $Y_{i j}$ is the lifetime net milk revenues per year in cow $i$ of herd $j ; \beta_{0}$ the intercept; $u_{0 j}$ a random-intercept effect of herd; $\beta_{\mathrm{m}}$ regression coefficients expressing included fixed effects; $X_{\mathrm{m} i j}$ fixed covariates; and $e_{i j}$ a random term at the cow level. Satterthwaite denominator degrees of freedom were used.

Initially, 35 potentially interesting independent variables were tested one by one, by including only the tested effect and a random herd effect. Continuous variables were centered by subtracting the overall mean and tested with polynomial extensions to the third degree. Eighteen variables were considered eligible for further analysis based on a $\mathrm{P}_{F} \leq 0.30$. The model was then built by forcing in a random-intercept effect of herd identity and important confounders, based on earlier research (variables expressing housing system for lactating cows and cow breed), initially including all eligible variables and their polynomial extensions, and by then excluding or reintroducing them one at a time in a manual stepwise manner. Only predictors that were (i) forced in, (ii) significant at $\mathrm{P}_{F}=0.05$, or (iii) confounders of rearing effects (changing significant coefficient estimates by $>10 \%$ ) were retained in the final model. Relevant one-way interactions were tested and included if $\mathrm{P}_{F} \leq 0.05$. To check for multicollinearity, each of the predictors was regressed on all the rest paying attention to the coefficients of determination, which did not exceed 0.55 . Residual analysis revealed no signs of non-normality or heteroscedasticity.

Independent variables expressing the following factors were tested for inclusion in the model, but were not retained: herd size, existence of explicit owner aims for replacement rearing, season of birth, housing system from birth to 3 mo, number of changes of housing system until 1st calving, ammonia concentration in buildings for calves or heifers, diarrhea and respiratory disease from birth to $3 \mathrm{mo}$ and from 3 to $7 \mathrm{mo}$, total herd disease incidence risk from birth to $4 \mathrm{mo}$, concentrate ration at 11-16 mo, prepubertal growth rate, grazing during rearing, grazing later in the autumn than 31 October during rearing, turning in from 
pasture on the day of 1st calving, time pre calving for introduction of heifers into the cow barn, time before 1st calving for concentrate increase, increase in concentrates to heifers during the last 2 mo pre calving, total concentrate increase around 1st calving, season of $1 \mathrm{st}$ calving, herd median age at 1 st calving, body condition score at 1 st calving, and geometric herd mean milk cell count in 2001.

Back-transformed least-squares means were calculated for different combinations of categorical predictors. For the presentation of associations, $95 \%$ confidence intervals, $\mathrm{P}$ values for t-tests comparing different predictor levels, and $\mathrm{P}$ values for $F$-tests of whole effects were calculated from estimates of coefficients and their standard errors. The influence of continuous predictors was illustrated graphically by displaying back-transformed leastsquares means.

\section{Results}

\subsection{General observations}

Mild or severe diarrhea before 7 mo of age had occurred in $11 \%$ of the cows, and mild or severe respiratory disease during the same time period in $11 \%$. The majority of these cases were mild. The mean $( \pm \mathrm{SD})$ prepubertal growth rate was $669( \pm 109) \mathrm{g} / \mathrm{day}$ and $9.5 \%$ of the animals had a daily weight gain >800 g. First calvings occurred between August 1999 and April 2003, and by 31 December 2001, $98 \%$ of the cows had calved. Mean ( \pm SD; range) age at 1 st calving was $28.3( \pm 3.97 ; 17.0-55.6)$ mo. The median herd size was 62 cows (range 30 -174 cows). During their productive lifetime, $31 \%$ of the cows had at least one case of veterinary-reported clinical mastitis, which accords well with data from the Swedish Dairy Association (2009). The medians (interquartile ranges, IQR) of composite cow and herd milk cell counts were 78,200 $(45,200-137,000)$ and 80,700 $(69,200-107,000)$ cells $/ \mathrm{ml}$, respectively.

\subsection{Life length, production, rearing costs and net revenues}

Median observed productive lifetime was 26.9 mo (range 2 days - 77.4 mo). Lifetime milk production ranged from 3181 to 13,971 (mean \pm SD 9209 \pm 1428 ) $\mathrm{kg} \mathrm{ECM} / \mathrm{cow}-\mathrm{yr}$. Lifetime rearing costs ranged from 169 to 249,000 (median 631; IQR $389-1168$ ) $€ / y r$, the highest value found in a cow that was culled 2 days after 1st calving and most low values in cows with long productive lives. Lifetime net milk revenues ranged from -247,364 to 2487 (median 1169; IQR 583 - 1513) €/cow-yr (transformed values had a mean \pm SD of 7.3 \pm 0.71 ). The relationship between lifetime rearing costs and net milk revenues was strong and negatively linear, with cows well ordered according to their productive life length (Fig. 1).

Results from the model of milk revenues are shown in Table 2 and Figs. 2-4. Revenues were almost linearly related to calving age, with a predicted value of $1513 € /$ cow-yr at 24 mo calving age, $74 € /$ cow-yr higher than at 28 mo (Fig. 2). Cows that had been housed in small slatted pens ( $\leq 7$ calves) and litter pens ( $\leq 12$ calves) from 3 to 7 mo of age had predicted revenues 846 and $894 € / y r$, respectively, higher than cows that had not been kept in pens but in tie-stalls ( $\mathrm{P}=0.048$ and 0.044). Swedish Red cows had revenues $662 € / \mathrm{yr}$ higher if they had been kept in large slatted pens ( $>7$ calves) instead of large litter pens ( $>12$ calves) $(\mathrm{P}=0.019)$. However, looking at small and large pen categories separately, we did not find cows that had been housed in litter pens to produce higher net milk revenues than cows housed in slatted pens. Nor did we find small calf pens to result in higher revenues than large calf pens, comparing them within slatted and litter pen categories separately. There was a curvilinear relationship between body condition score at breeding and lifetime net milk revenues, with 
scores $<3$ (176 cows) having successively higher and scores $>4$ (21 cows) successively lower predicted values (Fig. 3).

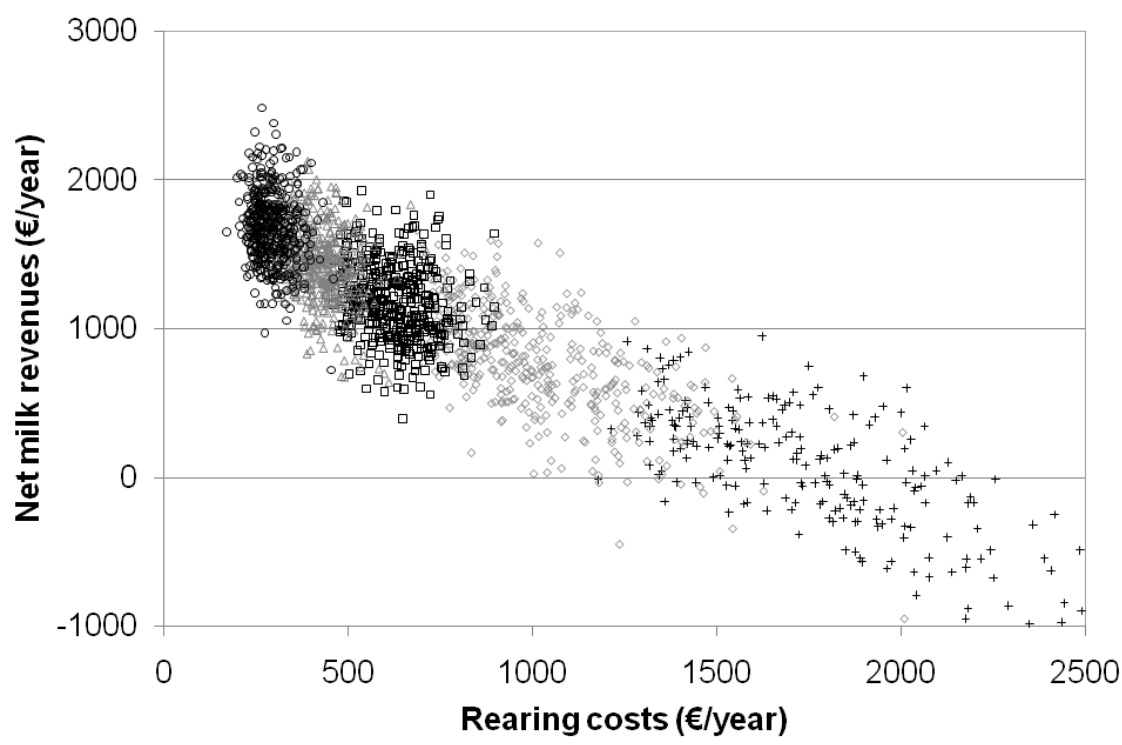

Fig. 1. Estimated rearing costs and lifetime net milk revenues per year in 2127 Swedish dairy cows born during 1998 in 110 herds. Dots of different types represent cow observations divided in fifths by quintiles of length of productive life.

Swedish Holsteins had predicted revenues $412 € /$ yr higher than Swedish Red cows $(\mathrm{P}=0.0002)$. Predicted revenues generally increased with year of 1 st calving, except for cows calving in 2003 which had revenues $2996 € / y r$ lower than cows calving in $2002(\mathrm{P}=0.0032)$, the former having a mean life length of only 3.8 mo. A geometric mean cow milk cell count below 100,000 cells/ml affected predicted revenues marginally; however, revenues dropped drastically with cell counts exceeding 1,200,000 cells/ml (Fig. 4).

Variance partitioning based on an empty model (random herd only) indicated that $30 \%$ of the total variation in net milk revenues reside on the herd level, and the remaining $70 \%$ on the cow level.

\section{Discussion}

This study reveals effects of several factors related to heifer rearing on lifetime milk revenues. We assumed cow net revenues to be a function of the length of productive life, milk production, milk price, and costs for replacement rearing and cow feed. Both lifetime milk production and rearing costs were spread over the entire productive life to arrive at yearly net revenues, potentially useful for assessing the profitability of the dairy enterprise. A long productive life will counteract high costs for rearing or a low milk production, and there might thus be conflicting effects of a risk factor on culling risk and milk production. Using data from the same cows, we have earlier found a high calving age - at least up to 28 mo - to be associated with both a high milk production in 1st lactation (Svensson and Hultgren, 2008) and an increased risk of culling (Hultgren and Svensson, 2009). To our knowledge, there are no previous studies of effects of calving age on lifetime milk production or milk revenues.

It should be kept in mind that the estimates of rearing and feed costs were based on templates developed for production support and advisory purposes in Sweden. Consequently, the estimates did not reflect actual conditions in studied herds and animals, except for calving age. Tozer and Heinrichs (2001) calculated rearing costs to increase by approximately $14 \$$ 
Table 2

Linear mixed model of net milk revenues ( $€ /$ cow-yr), based on 2127 Swedish dairy cows born during 1998 in 110 herds; number of observations used, least-squares means (LSM), their 95\% confidence intervals (CI), degrees of freedom in $F$-test, $F$ values and $\mathrm{P}$ values.

\begin{tabular}{|c|c|c|c|c|c|c|c|c|}
\hline Fixed effect & Level & $n$ & LSM & $95 \% \mathrm{CI}$ & $\mathrm{P}_{t}^{\mathrm{a}}$ & $\begin{array}{l}\text { Numerator and } \\
\text { denominator df }\end{array}$ & $F$ & $\mathrm{P}_{F}^{\mathrm{b}}$ \\
\hline Intercept & - & 1860 & - & - & $<0.0001$ & - & - & - \\
\hline \multirow[t]{3}{*}{ Breed } & Swedish Red & 942 & 463 & $-26.3-883$ & - & \multirow[t]{3}{*}{2,1044} & \multirow[t]{3}{*}{14.3} & \multirow[t]{3}{*}{$<0.0001$} \\
\hline & Swedish Holstein & 870 & 875 & $517-1205$ & 0.0002 & & & \\
\hline & Other or mixed & 48 & -827 & $-2404-252$ & 0.0054 & & & \\
\hline \multirow{5}{*}{$\begin{array}{l}\text { Housing from } \\
3 \text { to } 7 \mathrm{mo}\end{array}$} & Slatted pen $\leq 7$ calves & 839 & 500 & $-119-997$ & - & \multirow[t]{5}{*}{4,989} & \multirow[t]{5}{*}{1.68} & \multirow[t]{5}{*}{0.15} \\
\hline & Slatted pen $>7$ calves & 197 & 157 & $-579-753$ & 0.32 & & & \\
\hline & Litter pen $\leq 7$ calves & 583 & 548 & $54.0-966$ & 0.83 & & & \\
\hline & Litter pen $>7$ calves & 157 & 403 & $-552-1084$ & 0.78 & & & \\
\hline & Other ${ }^{\mathrm{C}}$ & 84 & -346 & $-1722-607$ & 0.048 & & & \\
\hline \multirow{3}{*}{$\begin{array}{l}B C S^{\mathrm{d}} \text { at } 1 s t \\
\text { breeding }\end{array}$} & (Continuous) & 1860 & \multirow{3}{*}{\multicolumn{2}{|c|}{ See Figure 2}} & 0.19 & 1,1827 & 1.68 & 0.19 \\
\hline & Quadratic extension (Continuous) & & & & 0.057 & 1,1820 & 3.63 & 0.057 \\
\hline & Cubic extension (Continuous) & & & & 0.028 & 1,1809 & 4.81 & 0.028 \\
\hline \multirow{5}{*}{$\begin{array}{l}\text { Year of } 1 s t \\
\text { calving }\end{array}$} & 1999 & 6 & 146 & $-1379-1027$ & 0.14 & \multirow[t]{5}{*}{4,1793} & \multirow[t]{5}{*}{3.11} & \multirow[t]{5}{*}{0.015} \\
\hline & 2000 & 1342 & 706 & $443-930$ & 0.013 & & & \\
\hline & 2001 & 496 & 608 & $326-857$ & 0.018 & & & \\
\hline & 2002 & 13 & 986 & $289-1470$ & 0.0032 & & & \\
\hline & 2003 & 3 & -2010 & $-6373-437$ & - & & & \\
\hline $\begin{array}{l}\text { Age at 1st } \\
\text { calving }\end{array}$ & (Continuous) & 1860 & \multicolumn{2}{|c|}{ See Figure 3} & 0.0006 & 1,1738 & 11.8 & 0.0006 \\
\hline \multirow{3}{*}{ Cow housing } & Cubicles & 456 & 613 & $27.5-1093$ & - & \multirow[t]{3}{*}{2,370} & \multirow[t]{3}{*}{7.62} & \multirow[t]{3}{*}{0.0006} \\
\hline & Short-stalls & 1011 & 605 & $110-1023$ & 0.98 & & & \\
\hline & Long-stalls & 393 & -581 & $-1718-267$ & 0.0003 & & & \\
\hline $\begin{array}{l}\text { Cow milk cell } \\
\text { count }\end{array}$ & (Continuous) & 1860 & \multicolumn{2}{|c|}{ See Figure 4} & $<0.0001$ & 1,1766 & 111 & $<.0001$ \\
\hline Housing from & Slatted pen $\leq 7$ calves $*$ Sw. Red & 446 & 692 & $262-1050$ & - & 8,1453 & 2.45 & 0.012 \\
\hline 3 to $7 \mathrm{mo}^{*}$ & Slatted pen $\leq 7$ calves $*$ Sw. Holstein & 383 & 753 & $351-1118$ & 0.55 & & & \\
\hline \multirow[t]{13}{*}{ Breed } & Slatted pen $\leq 7$ calves $*$ Other or mixed & 10 & -31.3 & $-2051-1107$ & 0.24 & & & \\
\hline & Slatted pen $>7$ calves $*$ Sw. Red & 73 & -112 & $-905-521$ & 0.0006 & & & \\
\hline & Slatted pen $>7$ calves $*$ Sw. Holstein & 117 & 545 & $-3.89-1014$ & 0.45 & & & \\
\hline & Slatted pen $>7$ calves $*$ Other or mixed & 7 & -18.5 & $-1732-1032$ & 0.20 & & & \\
\hline & Litter pen $<7$ calves * Sw. Red & 332 & 686 & $239-1060$ & 0.96 & & & \\
\hline & Litter pen $\leq 7$ calves * Sw. Holstein & 225 & 922 & $546-1262$ & 0.052 & & & \\
\hline & Litter pen $\leq 7$ calves * Other or mixed & 26 & -98 & $-1216-694$ & 0.023 & & & \\
\hline & Litter pen $>7$ calves $*$ Sw. Red & 54 & 773 & $50.1-1298$ & 0.77 & & & \\
\hline & Litter pen $>7$ calves * Sw. Holstein & 100 & 890 & $399-1311$ & 0.32 & & & \\
\hline & Litter pen $>7$ calves $*$ Other or mixed & 3 & -819 & $-5165-1068$ & 0.15 & & & \\
\hline & Other * Sw. Red & 37 & 127 & $-968-934$ & 0.14 & & & \\
\hline & Other * Sw. Holstein & 45 & 1192 & $749-1545$ & 0.010 & & & \\
\hline & Other * Other or mixed & 2 & -4921 & $-16774--416$ & 0.0030 & & & \\
\hline Cow housing & Cubicles $*$ Sw. Red & 212 & 540 & $-10.4-999$ & - & 4,1285 & 4.03 & 0.003 \\
\hline * Breed & Cubicles $*$ Sw. Holstein & 221 & 883 & $464-1257$ & 0.027 & & & \\
\hline & Cubicles $*$ Other or mixed & 23 & 379 & $-1120-1280$ & 0.77 & & & \\
\hline & Short-stalls * Sw. Red & 477 & 512 & $-11.9-947$ & 0.88 & & & \\
\hline & Short-stalls * Sw. Holstein & 514 & 1004 & $652-1321$ & 0.0087 & & & \\
\hline & Short-stalls * Other or mixed & 20 & 212 & $-838-950$ & 0.41 & & & \\
\hline & Long-stalls * Sw. Red & 253 & 329 & $-265-822$ & 0.34 & & & \\
\hline & Long-stalls $*$ Sw. Holstein & 135 & 724 & $240-1141$ & 0.41 & & & \\
\hline & Long-stalls * Other or mixed & 5 & -5091 & $-12809--1332$ & 0.0001 & & & \\
\hline
\end{tabular}

${ }^{\mathrm{a}} \mathrm{P}$ value of class based on a Student $t$-test; for categorical predictors, comparing LSM with base level; for continuous predictors, comparing coefficient estimate with 0 .

${ }^{\mathrm{b}} \mathrm{P}$ value of predictor based on an $F$-test.

${ }^{\mathrm{c}}$ Mainly tie-stalls.

${ }^{\mathrm{d}}$ Body condition score. 


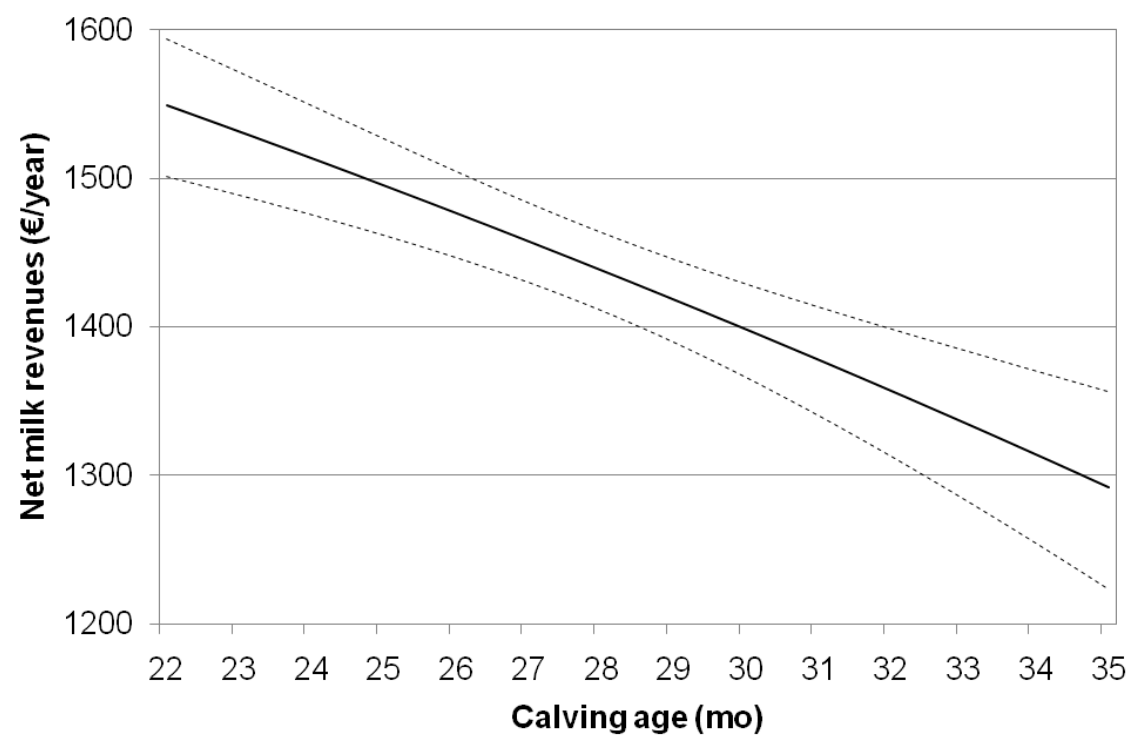

Fig. 2. Predicted net milk revenues in relation to age at 1st calving in a Swedish Holstein cow, housed in a slatted pen with $\leq 7$ calves from 3 to 7 mo of age, with a body condition score of 3.3 at $1 \mathrm{st}$ breeding, calving in year 2000, housed in a cubicle system and having a lifetime mean milk cell count of 130,000 cells $/ \mathrm{ml}$. Least-squares means from a linear mixed model based on data from 1860

Swedish dairy cows born during 1998 in 104 herds; milk price set to $0.3 € / \mathrm{kg}$ ECM; dashed lines show $95 \%$ confidence limits.

(or $16 €$, using the exchange rate of August 2001) for each month of delayed calving. Our estimations landed at $36.9 €$ per additional month.

Recommendations to farmers to breed for early calving is mainly based on findings of a longer productive life, a higher total lifetime production and reduced rearing costs at lower calving ages. Nilsforooshan and Edriss (2004) reported an increased productive lifetime in cows calving at the first time at 21 to 23 mo and shorter in animals calving at $>32$ mo.

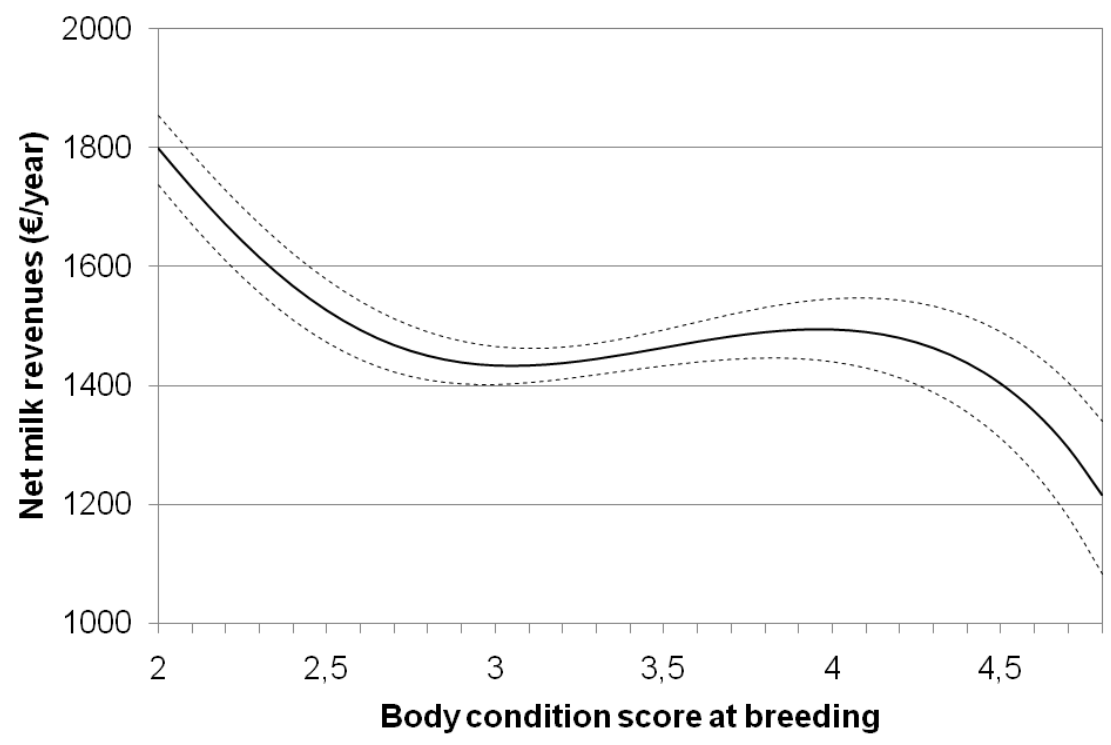

Fig. 3. Predicted net milk revenues in relation to body condition score at 1 st breeding in a Swedish Holstein cow, housed in a slatted pen with $\leq 7$ calves from 3 to 7 mo of age, calving in year 2000 at the age of $28 \mathrm{mo}$, housed in a cubicle system and having a lifetime mean milk cell count of 130,000 cells/ml. Least-squares means from a linear mixed model based on data from 1860 Swedish dairy cows born during 1998 in 104 herds; milk price set to $0.3 € / \mathrm{kg}$ ECM; dashed lines show 95\% confidence limits. 




Fig. 4. Predicted net milk revenues in relation to lifetime mean milk cell count in a Swedish Holstein cow, housed in a slatted pen with $\leq 7$ calves from 3 to 7 mo of age, with a body condition score of 3.3 at 1 st breeding, calving in year at the age of $28 \mathrm{mo}$ and housed in a cubicle system. Least-squares means from a linear mixed model based on data from 1860 Swedish dairy cows born during 1998 in 104 herds; milk price set to $0.3 € / \mathrm{kg}$ ECM; dashed lines show $95 \%$ confidence limits.

However, when calving between 24 and 31 mo, as most animals do, productive lifetime was almost constant. A similar pattern was reported by Schneider et al. (2007). It is wellknown that milk production in 1st lactation increases with age at calving (Hoffman et al., 1996; Mäntysaari et al., 2002; Svensson and Hultgren, 2008), presumably due to a lower energy requirement for growth in older animals. At the same time, a high calving age is also known to be associated with a lower lifetime milk yield (Lin et al., 1988; Nilsforooshan and Edriss, 2004) and with higher heifer rearing costs (Tozer and Heinrichs, 2001). This study provides evidence that lifetime net milk revenues increase with a lower calving age, at least down to $22 \mathrm{mo}$, thus justifying current recommendations.

We hypothesized a negative influence of severe calfhood illness but there were relatively few such cases, resulting in low statistical power. Svensson and Hultgren (2008) found a reduced milk production in 1st lactation in cows that were reported with diarrhea before 3 mo of age. On the other hand, Warnick et al. (1995) failed to detect an association between calf morbidity and subsequent first-lactation milk production, using farmer-reported data on calf diseases in 25 commercial dairy herds.

A negative correlation between body condition score at breeding and milk yield has been reported by Silva et al. (2002), who suggested that increased body fatness is a better predictor of impaired mammary development than the prepubertal growth rate. We found the relationship with lifetime net milk revenues to be curvilinear, with thin cows having higher and fat cows having lower revenues. However, there were relatively few cows scoring $<3$ or $>4$ at 1 st breeding. We did not find a relationship between prepubertal growth and milk revenues, which further supports Silva et al. (2002).

We used five different categories of calf housing from 3 to 7 mo of age, based on current practices and basically reflecting type of flooring and group size. Svensson and Liberg (2006) found that a small group size reduced the incidence of clinical respiratory disease and increased growth rate before weaning. Calf housing in small groups might imply a lower level of stress from e.g. less competition of feed and, in the more standardized slatted pens, more lying space. In the present study, housing in other systems than group pens (including tiestalls and, in one herd, cubicles) from 3 to 7 months of age was associated with the lowest net 
milk revenues. Housing of young calves in tie-stalls is probably stressful and it is not allowed according to current Swedish legislation. Cubicle housing was associated with even larger groups than pen housing, which might have increased stress further. Mogensen et al. (1999) found that access to bedding during rearing tends to increase milk production $84 \mathrm{~d}$ postpartum comparing with housing on a fully slatted floor. Due to the differing cut-offs for pen size in the present study, some of the five calf housing categories might not be directly comparable.

In our study of first-lactation production (Svensson and Hultgren, 2008) we found that cows in tie-stalls produce more than cows in cubicles. We did not see a corresponding effect on net milk revenues in the present study, based on observations in the same animals. In the early 2000s, traditional Swedish dairy herds were relatively small with tie-stalls, pasture grazing from May to September, and feeding based on grass-clover silage as roughage, but there was a strong trend towards larger herds and cubicle systems. In the latter, feed planning was usually carried out at the group level, with limited control over individual consumption, which is likely to reduce feed efficiency, although this effect is balanced by less labour per cow. Short-stalls are tie-stalls with constant access to the feeding platform, i.e. the ordinary type of tie-stalls in most countries, while long-stalls - mainly used in Northern Europe - are tie-stalls where the cows can be locked out from the manger at times when the farmer is not present. In the present data, long-stalls are likely to represent old barns, cubicle systems to be new and short-stall systems to be of intermediate age. We were, however, not able to consider cow-barn age in the analysis. Large operations can also be expected to be established more recently, and the net effect on lifetime milk production and net milk revenues is therefore hard to predict. We were not able to show any effect of herd size on milk revenues.

Earlier research (Mäntysaari et al., 2002; Moore et al., 1991) has revealed considerably higher production levels in Holsteins than in Red or Ayrshire cows. According to data from the Swedish milk recording scheme (Swedish Dairy Association, 2009), the two breeds produced equally much around 1985 but have parted gradually since, and in 2003, Holsteins produced almost $500 \mathrm{~kg}$ ECM/yr more. Smaller breeds (such as Jersey or Swedish Polled) were sparsely represented in our data. The present results suggest that cow breed also influences net milk revenues in the same direction.

High milk cell counts were associated with low net milk revenues. Reductions in milk yield have been described as a result of counts of 600,000 cells/ml (Hortet et al., 1999). Counts exceeding 1,200,000 cells/ml are likely to indicate clinical mastitis which is known to reduce the milk yield (Rajala-Schultz et al., 1999).

Milk revenues increased with year of calving during the first four calving years, which might reflect a general trend in milk production. However, calving in the last year recorded was associated with much lower revenues. The most likely explanation is that these cows had shorter productive lives simply because recordings were terminated and more long-lived cows could not be included.

In the present study, data were from 110 herds selected for geographical location, enrolment in official recording schemes, herd size, assumed capability of farmers to keep reliable calf records, and farmer willingness to participate in the study. The studied herds represented $22 \%$ of all dairy operations in the selected county, or $0.7 \%$ of all Swedish dairy establishments at the time of selection (Statistics Sweden, 1999). A comparison with 1500 randomly selected controlled operations with the same herd size in 1999 (Svensson et al., 2003), showed the study herds to be reasonably representative for Swedish dairy operations of 24-98 cows with regards to housing, feeding and management of calves and heifers. As reported by Svensson et al. (2006b), in the milk recording year when most heifers in the study calved (2000-2001), the herds were, however, larger and had a higher mean annual milk production than all Swedish dairy operations of 24-98 cows. Herd selection might therefore 
have introduced some bias with respect to the estimated lifetime milk production and its predictors.

The studied cows represented a fixed cohort of animals that calved in 1998 and were observed for more than four years after $98 \%$ of the cows had calved. The study design ensured that $86 \%$ of studied cows were observed until culling, death or selling off, i.e. during their entire productive life in the herds where they calved as heifers.

\section{Conclusions}

The present study provides evidence that a high age at 1st calving and a high body condition at 1 st breeding are associated with low lifetime net milk revenues. The results show that replacement rearing factors influence net milk revenues and support current recommendations to breed dairy heifers for calving at 24 mo for maximized net economic returns.

\section{Disclosure statement}

None of the authors have any financial, personal or other relationships that would inappropriately influence the scientific quality of this study. Jan Hultgren and Catarina Svensson received funding during the study period from organizations and companies related to Swedish livestock production for other research projects involving dairy cattle. Mats Pehrsson was employed by the Swedish Dairy Association during the whole study period, and was involved in the analysis and interpretation of data, and in the writing of the paper.

\section{Acknowledgements}

We acknowledge the interest and support of participating farmers and the contributions of Ulf Emanuelson, Sven-Ove Olsson and Kerstin Plym Forshell during the initiation and planning phases of the study. We also thank the Swedish Dairy Association for providing us with production, health and rearing cost data. Karin Lundborg, Lotta Andersson and Jonica Östlund performed valuable on-farm recordings, Gunilla Jacobsson assisted in data editing and staff from Freja Husdjur (formerly Skara Semin) Regional Dairy Association helped with data collection. The study was funded by the Swedish Farmers' Foundation for Agricultural Research. The funding source had no involvement in the collection, analysis, and interpretation of data, in the writing of the report or in the decision to submit the paper for publication.

\section{References}

Britney, J.B., Martin, S.W., Stone, J.B., Curtis, R.A., 1985. Analysis of early calfhood health status and subsequent dairy herd survivorship and productivity. Prev. Vet. Med. 3, 4552.

Gardner, R.W., Smith, L.W., Park, R.L., 1988. Feeding and management of dairy heifers for optimal lifetime productivity. J. Dairy Sci. 71, 996-999.

Hessle, A., Nadeau, E., Svensson, C., 2004. Feeding dairy calves and replacement heifers in south-western Sweden — a survey. Acta Agric. Scand. 54, 94-102.

Hoffman, P.C., Brehm, N.M., Price, S.G., Prill-Adams, A., 1996. Effect of accelerated postpubertal growth and early calving on lactation performance of primiparous Holstein heifers. J. Dairy Sci. 79, 2024-2031. 
Hortet, P., Beaudeau, F., Seegers, H., Fourichon, C., 1999. Reduction in milk yield associated with somatic cell counts up to 600000 cells/mL in French Holstein cows without clinical mastitis. Livest. Prod. Sci. 61, 33-42.

Hultgren, J., Svensson, C., 2009. Heifer rearing conditions affect length of productive life in Swedish dairy cows. Prev. Vet. Med. 89, 255-264.

Hultgren, J., Svensson, C., Maizon, D.O., Oltenacu, P.A., 2008. Rearing conditions, morbidity and breeding performance in dairy heifers in southwest Sweden. Prev. Vet. Med. 87, 244-260.

Lin, C.Y., McAlliater, A.J., Batra, T.R., Lee, A.J., 1988. Effects of early and late breeding of heifers on multiple lactation performance of dairy cows. J. Dairy Sci. 71, 2735-2743.

Mäntysaari, P., Ojala, M., Mäntysaari, A.E., 2002. Measures of before and after breeding daily gains of dairy replacement heifers and their relationship with first lactation milk production traits. Livest. Prod. Sci. 75, 313-322.

Mogensen, L., Sørensen, J.T., Hindhede, J., Nielsen, L.H., Kristensen, A.R., 1999. Effect of space allowance and access to bedding in slatted-floor housing systems during second year rearing on subsequent milk production of primiparous dairy cows. Acta Agric. Scand. Sect. A. Anim. Sci. 49, 49-56.

Moore, R.K., Kennedy, B.W., Schaffer, L.R., Moxley, J.E., 1991. Relationships between age and body weight at calving and production in fist lactation Ayshires and Holsteins. J. Dairy Sci. 74, 269-278.

Nilsforooshan, M.A., Edriss, M.A., 2004. Effect of age at first calving on some productive and longevity traits in Iranian Holsteins of the Isfahan Province. J. Dairy Sci. 87, 21302135.

Olsson, S.-O., Baekbo, P., Hansson, S.Ö., Rautala, H., Østerås, O., 2001. Disease recording systems and herd health schemes for production diseases. Acta Vet. Scand. (Suppl. 94), $51-60$.

Pirlo, G., Capelletti, M., Marchetto, G., 1997. Effect of energy and protein allowances in the diets of prepubertal heifers on growth and milk production. J. Dairy Sci. 80, 730-739.

Pirlo, G., Miglior, F., Speroni, M., 2000. Effect of age at first calving on production traits and on difference between milk yield returns and rearing costs in Italian Holsteins. J. Dairy Sci. 83, 603-608.

Rajala-Schultz, P.J., Grøhn, Y.T., McCulloch, C.E., Guard, C.L., 1999. Effects of clinical mastitis on milk yield in dairy cows. J. Dairy Sci. 82, 1213-1220.

Schneider, M. del P., Strandberg, E., Emanuelson, U., Grandinson, K., Roth, A., 2007. The effect of veterinary-treated clinical mastitis and pregnancy status on culling in Swedish dairy cows. Prev. Vet. Med. 80, 179-192.

Sejrsen, K., Huber, L.T., Tucker, H.A., Akers, R.M., 1982. Influence of nutrition on mammary development in pre- and postpubertal heifers. J. Dairy Sci. 65, 793-800.

Sejrsen, K., Purup, S., Vestergaard, M., Foldager, J., 2000. High body weight gain and reduced bovine mammary growth: physiological basis and implications for milk yield potential. Domest. Anim. Endocrinol. 19, 93-104.

Silva, L.F.P., Vandehaar, M.J., Whitlock, B.K., Radcliff, R.P., Tucker, H.A., 2002. Short communication: relationship between body growth and mammary development in dairy heifers. J. Dairy Sci. 85, 2600-2602.

Statistics Sweden, 1999. Jordbruksstatistisk årsbok 1999 (Yearbook of agricultural statistics 1999). Stockholm, Sweden. Report.

Strandberg, E., 1992. Lifetime performance in dairy cattle. Acta Agric. Scand. 42, 71-81.

Svensson, C., Hultgren, J., 2008. Associations between housing, management, and morbidity during rearing and subsequent first-lactation milk production of dairy cows in southwest Sweden. J. Dairy Sci. 91, 1510-1518. 
Svensson, C., Liberg, P., 2006. The effect of group size on health and growth rate of calves housed in pens with automatic milk feeders. Prev. Vet. Med. 73, 43-53.

Svensson, C., Lundborg, K., Emanuelson, U., Olsson, S.-O., 2003. Morbidity in Swedish dairy calves from birth to 90 days of age and individual calf-level risk factors for infectious diseases. Prev. Vet. Med. 58, 179-197.

Svensson, C., Hultgren, J., Oltenacu, P.A., 2006a. Morbidity in 3-7-month-old dairy calves in south-western Sweden and risk factors for diarrhea and respiratory disease. Prev. Vet. Med. 74, 162-179.

Svensson, C., Nyman, A.-K., Persson Waller, K., Emanuelson, U., 2006b. Effects of housing, management, and health of dairy heifers on first-lactation udder health in southern Sweden. J. Dairy Sci. 89, 1990-1999.

Swedish Dairy Association, 2009. Cattle Statistics 2009. Stockholm, Sweden. Report.

Tozer, P.R., Heinrichs, A.J., 2001. What affects the costs of raising replacement dairy heifers: a multiple-component analysis. J. Dairy Sci. 84, 1836-1844.

Warnick, L.D., Erb, H.N., White, M.E., 1995. Lack of association between calf morbidity and subsequent first lactation milk production in 25 New York Holstein herds. J. Dairy Sci. 78, 2819-2830.

Zanton, G.I., Heinrichs, A.J., 2005. Meta-analysis to assess effect of prepubertal average daily gain of Holstein heifers on first-lactation production. J. Dairy Sci. 88, 3860-3867. 